\title{
HUBUNGAN USIA AWAL PEMBERIAN MP-ASI DENGAN KEJADIAN DIARE DI DESA LUBUK PALAS KEC. SILAU LAUT TAHUN 2021
}

\author{
Fifi Ria Ningsih Safari ${ }^{1}$, Eliza Bestari Sinaga ${ }^{2}$ \\ ${ }^{1,2}$ Akbid Kholisatur Rahmi Binjai \\ Fifiria58@yahoo.com, elizabestari69@gmail.com
}

\begin{abstract}
Complementary Foods for Mother's Milk (MP-ASI) are foods or drinks that contain nutrients, which are given to infants to meet their nutritional needs. As babies get older, after babies are 6 months old, they are introduced to complementary foods to meet their nutritional needs. The impact of giving MP-ASI too early is more frequent constipation, diarrhea, constipation, cough, runny nose and fever, compared to babies who are only exclusively breastfed. This study aims to determine the relationship between early breastfeeding complementary feeding and the incidence of diarrhea in Lubuk Palas Village, Silau Laut District in 2021. This type of research was cross sectional with a correlational research design. The population in this study were all mothers who have babies 0-6 months who live in Lubuk Palas Village, Silau Laut District in 2021, as many as 35 people, while the samples taken in the study were all mothers who had babies under 0-6 months as many as 35 people. . The results showed that there was a relationship between the availability of clean water and healthy latrines with the incidence of diarrhea in children under five. There is a relationship between early breastfeeding complementary feeding and the incidence of diarrhea in Lubuk Palas Village, Silau Laut Regency in 2021. It is hoped that mothers who have babies at an early age in Lubuk Palas Village, Silau Laut Regency can try to give exclusive breastfeeding until the baby is 6 months old.
\end{abstract}

Keywords: early age giving MP-ASI, diarrhea incidence

\section{PENDAHULUAN}

Makanan pendamping ASI (MPASI) adalah makanan atau minuman yang mengandung gizi, diberikan pada bayi untuk memenuhi kebutuhan gizinya. MP-ASI diberikan bersamaan dengan ASI mulai 6 bulan sampai 24 bulan. Seiring bertambahnya usia bayi, setelah bayi berusia 6 bulan, mulai diperkenalkan dengan makanan pendamping untuk memenuhi kebutuhan gizinya. (ning \& Zubaidah, 2016)
Hindari memberikan MP-ASI lebih awal atau kurang dari 6 bulan, dibawah 6 bulan daya imunitas bayi belum sempurna. Akibatnya, pemberian makanan sebelum 6 bulan mengundang kuman-kuman untuk masuk ketubuhnya. Si bayi menjadi lebih mudah sakit (ning \& Zubaidah, 2016)

Hasil penelitian pusat penelitian dan pengembangan gizi dan makanan, Depertemen Kesehatan dan Organisasi Kesehatan Dunia (WHO) lebih dari 50\% bayi 
Indonesia sudah mendapatkan MP-ASI pada umur kurang dari satu bulan. Bahkan pada umur 2-3 bulan bayi sudah mendapatkan makanan padat (Sandjaja., 2009).

Angka kematian bayi (AKB) di Indonesia adalah 34/1000 kelahiran hidup (DepKes RI, 2011) dengan harapan pada tahun 2015 Angka Kematian Bayi (AKB) di Indonesia turun menjadi 15/1000 kelahiran hidup. Karena ibu kurang mendapat informasi tentang manfaat ASI eksklusif dan makanan pendamping ASI diberikan pada usia kurang dari 6 bulan.

Pemberian makanan padat pada bayi tidak boleh terlalu dini karena : makanan padat yang mengandung protein, akan menambah padat ginjal, dan menimbulkan peninggian konsentrasi natrium dan ureum dalam plasma darah. Pemberian makanan padat terlalu dini pada sebagian bayi akan meningkatkan masuknya protein asin. Dampak pemberian MP-ASI terlalu awal lebih sering terserang konstipasi, diare, sembelit, batuk, pilek dan demam, dibandingkan bayi yang hanya diberi ASI eksklusif (Simbolon, 2019).

Dari Hasil beberapa penelitian menyatakan bahwa keadaan kurang gizi pada bayi dan anak disebabkan karena kebiasaan pemberian Makanan Pendamping Asi (MPASI) yang tidak tepat (Angriani et al., 2019). Di Provinsi Sumatra Utara berdasarkan data dari dinas kesehatan Sumatra Utara pada tahun 2013 terdapat 203.317 kasus diare di sarana kesehatan dengan angka kematian sebanyak 12 kasus (Prabhakara, 2010)

Survey pendahuluan yang peneliti lakukan bahwa ditemukan masih ada ibu yang memberikan MP-ASI terlalu awal. Berdasarkan servey pendahuluan yang peneliti lakukan maka peneliti tertarik untuk meneliti "Hubungan Usia Awal Pemberian MP-ASI dengan Kejadian Diare di Desa Lubuk Palas Kecamatan Silau Laut Tahun $2021 "$.

\section{METODE}

Penelitian ini merupakan jenis penelitian analisa kolerasi ini menggunakan jenis penelitian dengan pendekatan cross sectional yaitu variable sebab akibat yang terjadi pada objek penelitian di ukur atau dikumpulkan pada waktu yang sama dan tiap subjek penelitian diobservasi sekali saja. Penelitian ini dilakukan di Desa Lubuk Palas Kecamatan Silau Laut Kabupaten Asahan 2021. Populasi dalam penelitian ini adalah seluruh ibu yang memiliki bayi 0-6 bulan yang berdomisili di Desa Lubuk Palas Kecamatan Silau Laut tahun 2021 sebanyak 35 orang, sedangkan sampel yang diambil dalam penelitian adalah seluruh ibu yang memiliki bayi dibawah 0-6 bulan sebanyak 35 orang. Sumber data dalam penelitian ini adalah data primer dan data sekunder.Data primer yaitu data yang diperoleh dari responden (sampel) langsung melalui kuiseoner yang telah disiapkan, kuisioner 
yang telah dibuat kemudian dilakukan uji coba terhadap responden.

Data primer dalam penelitian ini adalah:

a. Usia awal terhadap pemberian MPASI.

b. Kejadian diare berdasarkan pemberian MP-ASI pada usia awal.

Data sekunder adalah data yang diperoleh peneliti secara tidak langsung yaitu melalui data dari kelurahan. Setelah data dikumpulkan, data diolah dengan menggunakan program statistic (statistic data, analisis) dengan menggunakan Analisis Univariate (Analisis Deskripsif) dan analisis bivariate.

\section{HASIL DAN PEMBAHASAN}

\section{Hasil Penelitian}

\section{A. Analisis Univariat}

Tabel 1. Distribusi Frekuensi Berdasarkan Umur, pendidikan, Pekerjaan, Sumber Informasi ibu, usia awal bayi dan diberikan MP-ASI dan Kejadian Diare

\begin{tabular}{lll}
\hline \multicolumn{1}{c}{ Variabel } & n & \% \\
\hline Umur Ibu & & \\
17-25 tahun & 3 & 37 \\
$26-35$ tahun & 14 & 40 \\
$36-45$ tahun & 8 & 23 \\
\hline Jumlah & $\mathbf{3 5}$ & $\mathbf{1 0 0}$ \\
\hline Pendidikan Ibu & & \\
\hline SD & 10 & 29 \\
SMP & 7 & 20 \\
SMA & 13 & 37 \\
\hline PT & 5 & 14 \\
\hline Jumlah & $\mathbf{3 5}$ & $\mathbf{1 0 0}$ \\
\hline Pekerjaan Ibu & & \\
\hline PNS & 13 & 9 \\
Wiraswasta & 14 & 40 \\
IRT & 18 & 51 \\
\hline Jumlah & $\mathbf{3 5}$ & $\mathbf{1 0 0}$ \\
\hline Sumber Informasi & & \\
\hline Belum Pernah Dpt Informasi & 7 & 20
\end{tabular}

\begin{tabular}{lll} 
Buku & 6 & 17 \\
Radio/ TV & 13 & 37 \\
Tenaga Kesehatan & 9 & 26 \\
\hline Jumlah & $\mathbf{3 5}$ & $\mathbf{1 0 0}$ \\
\hline Usia Bayi & & \\
\hline 0-2 bulan & 7 & 20 \\
3-4 bulan & 12 & 24 \\
5-6 bulan & 16 & 46 \\
\hline Jumlah & $\mathbf{3 5}$ & $\mathbf{1 0 0}$ \\
\hline Diberikan MP-ASI & & \\
\hline Diberikan & 21 & 60 \\
Tidak diberikan & 14 & 40 \\
\hline Jumlah & $\mathbf{3 5}$ & $\mathbf{1 0 0}$ \\
\hline Kejadian Diare & & \\
\hline Pernah & 20 & 57 \\
Tidak Pernah & 15 & 43 \\
Jumlah & $\mathbf{3 5}$ & $\mathbf{1 0 0}$ \\
\hline
\end{tabular}

Berdasarkan data pada Tabel diatas dapat diketahui bahwa dari 35 sampel ibu yang memiliki bayi mayoritas umur 26-35 tahun sebanyak 14 orang (40 \%), berdasarkan pendidikan ibu mayoritas 13 orang (37\%) memiliki pendidikan SMA, dilihat dari pekerjaan ibu mayoritas sebanyak 18 orang (51\%) adalah ibu rumah tangga, berdasarkan informasi mayoritas didapat dari radio/tv sebanyak 13 orang (37\%), Usia awal bayi mayoritas 5-6 bulan sebanyak 16 orang (46\%) sedangkan berdasarkan Usia awal diberikan MP-ASI Mayoritas diberikan sebanyak 21 orang (60\%). Berdasarkan Kejadian diare mayoritas pernah terjadi sebanyak 20 orang (57\%).

\section{B. Analisis Bivariat}

Tabel 2. Hubungan Usia Awal Pemberian MP ASI Dengan Kejadian Diare

\begin{tabular}{|c|c|c|c|c|c|c|c|}
\hline \multirow{3}{*}{$\begin{array}{l}\text { Variabel Isia Amal } \\
\text { Pemberian IPPASI }\end{array}$} & \multicolumn{4}{|c|}{ Kejadian Diare } & \multirow{2}{*}{\multicolumn{2}{|c|}{ Jumlah }} & $P$ \\
\hline & \multicolumn{2}{|c|}{ Pernah } & \multicolumn{2}{|c|}{ Tidak Pernah } & & & \\
\hline & ॥ & $\%$ & n & $\%$ & n & $\%$ & \\
\hline Diberikan & 20 & 95 & 1 & 5 & 21 & 100 & \\
\hline Iidak Diberikan & 0 & 0 & 14 & 100 & 14 & 100 & 0,000 \\
\hline
\end{tabular}


Berdasarkan Tabel diatas diketahui Hasil uji chi-square yang di lakukan terhadap hubungan usia awal pemberian MP-ASI dengan kejadian maka diperoleh $\mathrm{X} 2$ hitung = 17,500a $>\mathrm{X} 2$ tabel $=3,841$ dengan $\mathrm{df}=1$ dan taraf signifikan 0,05 dengan nilai Asymp. Sig $(0,000)$ yang terbukti $(\mathrm{P}<0,05)$ maka Ho ditolak Ha diterima. Hal ini berarti "Ada hubungan Usia Awal Pemberian MPASI dengan Kejadian Diare".

\section{PEMBAHASAN}

Dari hasil penelitian yang telah diteliti terdapat 21 responden $(60 \%)$ yang memberikan MP-ASI. Jumlah ini lebih besar bila dibandingkan dengan bayi yang tidak di beri MPASI yaitu sebesar 14 responden (40\%). Hal ini sesuai dengan data di tabel distribusi usia awal yaitu dari hasil penelitian yang telah diteliti terdapat mayoritas bayi yang berusia awal 5-6 bulan berjumlah 16 bayi (46\%), dan minoritas usia awal 0-2 bulan berjumlah 7 bayi (20\%).

Usia adalah rentang kehidupan yang diukur dengan tahun. Dikatakan usia awal pada bayi adalah usia 0-6 bulan. Dimana pada masa ini bayi hanya diberikan ASI eksklusif saja, tanpa diberi cairan lain baik dalam bentuk apapun kecuali sirup obat (Dewi, 2010). Manfaat pemberian ASI eksklusif yaitu ASI sebagai nutrisi yang merupakan sumber gizi yang sangat ideal dengan komposisi yang seimbang dan di sesuaikan dengan bayi yang tidak mendapatkan ASI Eksklusif . Bila bayi sehat tentu akan lebih berkembang kepandaiannya dibandingkan bayi yang sering sakit terutama bila sakitnya berat. ASI Eksklusif juga dapat meningkatkan jalinan kasih sayang antara bayi dan ibu (Anjarsari \& Zubaidah, 2017)

Hasil penelitian ini sesuai dengan alasan ibu-ibu yang di temukan di masyarakat, yang mana paling sering dijumpai tidak memberikan ASI Eksklusif sampai bayi berusia minimal 6 bulan, yaitu karena merasa ASI tidak cukup untuk memenuhi kebutuhan bayinya, ibu merasa repot dengan pekerjaannya, untuk kesehatan bayinya, ibu mengatakan BB bayi akan cepat meningkat setelah diberi MP-ASI, dan kebiasaan ibu yang memang dari sejak dulu terbiasa memberikan MP-ASI kepada bayinya karna pecaya dengan memberikan MP-ASI anaknya akan lebih cepat kenyang.

Dari hasil penelitian yang telah diteliti terdapat 21 responden $(60 \%)$ yang sudah diberikan MP-ASI diawal usia dan 14 responden (40\%) yang tidak terkena diberikan. Menurut asumsi peneliti mayoritas responden yang pernah mengalami diare berjumlah 20 bayi (57\%), diare ini berpengaruh terhadap pemberian MP-ASI terlalu awal. Hasil penelitian ini sesuai dengan apa yang peneliti lihat dimasyarakat bahwa masih banyak ibu -ibu yang tidak peduli dengan penyakit diare. Ditandai dengan sedikitnya responden yang membawa 
anaknya ke pelayanan kesehatan untuk memeriksa atau mengobati diare. Padahaal diare merupakan penyakit yang berbahaya terutama pada bayi, apa bila tidak ditangani dengan segera bayi bisa mengalami dehidrasi. Oleh karena itu pemeriksaan dan pengobatan yang segera merupakan tindakan awal untuk menyelamatkan bayi dari bahaya.

Setelah dilakukan analisa kolerasi chi-square pada kolom Asymp. Sig. (2sided) menunjukkan nilai probalitas. Nilai Sig-nya adalah 0,000 yang berarti bahwa nilai $(\mathrm{p}<0,05)$, maka Ho ditolak dan $\mathrm{Ha}$ diterima dan berdasarkan nilai $\mathrm{X} 2$ hitung $=$ Value $=17,500^{\mathrm{a}}>\mathrm{X} 2$ tabel 3,841 dengan $\mathrm{df}$ $=1$ dan taraf signifikan 0,05. Maka dapat disimpulkan bahwa Ha diterima yaitu "Ada hubungan Usia Awal Pemberian MP-ASI dengan Kejadian diare di Desa Lubuk Palas Kecamatan Silau Laut Tahun 2021"

Hal ini sesuai dengan referensi yang menyatakan bahwa Pemberian ASI bagi bayi bermanfaat untuk meningkatkan daya tahan tubuh karena ASI adalah cairan hidup yang mengandung zat kekebalan yang akan melindungi bayi dari berbagai penyakit infeksi bakteri, virus, parasit, dan jamur (View of Analisis Faktor Yang Memengaruhi Pemberian MPASI Dini, n.d.)

Menurut asumsi penelitian, ibu yang memililki bayi usia awal yang merupakan responden dalam penelitian ini mengungkapkan alasan mengapa anaknya terserang diare yaitu 14 responden (40\%) karena memberikan MP-ASI pada bayi usia awal, dan 1 responden (3\%) karena kurang bersihnya dot botol tempat susu bayi.

Hal tersebut di dukung pada survey penelitian di RSUD Dr. Pirngadi Medan (RSPM) penyakit diare ini masih menjadi kasus dengan penderita cukup banyak. Dalam setiap harinya dijumpai lima bayi yang menderita diare akibat pemberian MPASI yang terlalu awal. Di kota Medan, sepanjang tahun 2011, tercatat 42.050 kasus diare pada bayi dan balita, dimana pasienya sempat mendapat perawatan di 39 Puskesmas atau di RSUD Dr. Pirngadi Medan (Prabhakara, 2010)

\section{KESIMPULAN DAN SARAN}

\section{Kesimpulan}

Berdasarkan hasil penelitian maka dapat disimpulkan bawha terdapat hubungan yang signifikan antara hubungan usia awal pemberian MP-ASI dengan kejadian diare.

\section{Saran}

Disarankan pada ibu yang memiliki bayi di usia dini di Desa Lubuk Palas Kecamatan Silau Laut, sebaiknya berusaha memberikan ASI eksklusif sampai bayi berusia 6 bulan.

\section{DAFTAR PUSTAKA}

Angriani, S., Merita, M., \& Aisah, A. (2019). Hubungan Lama Pemberian Asi Dan Berat Lahir Dengan Kejadian Stunting Pada Balita Di Wilayah Kerja Puskesmas Siulak Mukai Kabupaten 
Kerinci Tahun 2019. Jurnal Akademika

Baiturrahim Jambi, 8(2), 244-251.

https://doi.org/10.36565/JAB.V8I2.175

Anjarsari, L., \& Zubaidah, Z. (2017).

Hubungan Dukungan Keluarga

terhadap ASI Ekslusif dengan

Pemberian MP-ASI pada Ibu Bekerja di

Desa Rembes Kecamatan Bringin

Kabupaten Semarang.

ning, suwarsih, \& Zubaidah, Z. (2016).

Hubungan Antara Kepatuhan Budaya

Dengan Waktu Pemberian Makanan

Pendamping Asi Di Desa Peniron

Kecamatan Pejagoan Kabupaten

Kebumen.

Prabhakara, G. (2010). Health Statistics

(Health Information System). In Short

Textbook of Preventive and Social

Medicine.

https://doi.org/10.5005/jp/books/11257

$-5$

Sandjaja. (2009). Kamus gizi: pelengkap kesehatan keluarga. 293.

Simbolon, D. (2019). Pencegahan Stunting Melalui Intervensi Gizi Spesifik Pada Ibu Menyusui Anak. Media Sahabat Cendekia, 36.

View of Analisis Faktor Yang Memengaruhi Pemberian MPASI Dini. (n.d.). Retrieved September 4, 2021, from http://jurnal.stikeswilliambooth.ac.id/in dex.php/Keb/article/view/99/89 